\title{
What Controls E-Participation? Government Presence on the Internet and Government Ineffectiveness
}

\author{
Fuad Hidayat $^{1}$, Budi Setiyono ${ }^{2}$, Ika Riswanti Putranti ${ }^{3}$, Ida Hayu Dwimawanti ${ }^{4}$, Hartuti \\ Purnaweni $^{5}$, M. Elfan Kaukab ${ }^{6}$ \\ $\left\{\right.$ elfan@unsiq.ac.id $\left.{ }^{6}\right\}$ \\ Universitas Diponegoro, Indonesia ${ }^{1,2,3,4,5}$ \\ Universitas Sains Al-Qur'an, Indonesia ${ }^{6}$
}

\begin{abstract}
This research contributes to the literature on e-participation by proposing a number of e-participation determinant variables. To do this, we assemble cross-section data using an accurate secondary data source and analyze it using the multiple regression equation models. Government asset management in this case is approached by government online presence in various fields of government. We tested this on 129 countries samples. The e-participation indicator is taken from the Global Innovation Index. After the analysis, it is found that the government online presence has a positive effect on e-participation and the government effectiveness has a negative effect on eparticipation. Meanwhile, public infrastructure and ecological sustainability and voice positively relate to e-participation. Education the use of ICT, and Islam have no significant effect on e-participation.
\end{abstract}

Keywords: Government, E-participation, Asset Management, Ecological Sustainability, ICT

\section{Introduction}

Many countries nowadays, regardless whether they are developed or developing ones, are competing to develop assets in the field of information technology [1]. Information and Communication Technology (ICT) asset management aims to encourage community participation, impact public value, and prevent such assets from being wasteful [2][3]. Supervision, control, and protection of assets stimulate the community to be involved in the government's vision, goals, and plans to improve the citizens' quality of life and expand the business and social opportunities [4].

Public participation in government allows the direct user, the community, to influence decision making which will affect not only those participating but also the society as a whole [5]. The government does not always know what public wants and whether the policies and programs they are running are truly effective, efficient, and well-targeted. Public participation enables the community to determine, report, or correct policies and programs that have been or will be carried out by the government to achieve the expected goals.

However, the scientific community think that we are still far from understanding the determinants of e-participation [6]. Empirical research has identified the factors associated with community participation in e-government and provided inconsistent results [6][9]. There are only a few researches examining the determinants of e-participation in terms of assets and infrastructure. On the other hand, many argue that it is hard for the government investment in 
e-government to have an impact on public participation [10][12]. In many cases, government investment in e-government is far from affecting the community participation [13][14]. Thus, the e-participation determinants are issues for both the government and the academics. We conducted this research to identify the factors associated with public participation in egovernment as the goal of utilizing information technology assets of public institutions.

\section{Theory and Hypothesis}

Two theories support this research variables, namely institutional theory and endogenous growth theory [15]. According to institutional theory, social behavior is determined by rules and norms as well as structure and routines and also authoritative guidelines in a society [16]. Rules and norms in this context are formulated by the government as a ruler in society [17]. Institutional factors such as ICT asset management, general asset management, environmental sustainability, freedom of speech, and government effectiveness can, therefore, play roles in eparticipation. Meanwhile, endogenous growth theory [18][19] states that the growth of a nation is influenced by the nation's internal processes, such as education, the use of ICTs, and socioeconomic indicators such as religion.

Jho and Song [20] argued that e-government aims to increase public access to political processes and deliberate public matters. Since public issues are easily found by the community, the more public problems are, the higher the community participation in egovernment is. This participation in turn increases government effectiveness, but not vice versa [21][22]. This is possible only if the government opens wide space for the public through ICT asset management. Therefore, the greater the presence of government online is, the greater public participation is in bringing problems to be addressed together. In line with this, we hypothesize that there is a positive influence of government asset management on eparticipation and vice versa, there is a negative influence of government effectiveness on eparticipation.

\section{Method}

Cross-sectional data of 2018 and 2019 were used to test our hypothesis. Samples were taken from 129 countries used by Duta et al. [23] to calculate the 2019 Global Innovation Index. Another database used is 2018 Good Governance data from The World Bank [24] for voice variables and Pew Research Center [25] for the percentage of Muslim population.

The independent variables in this study were taken from a number of previous studies Azam and Laka et al. [8][15] and their logical relevance to the dependent variable, in this case, e-participation. The values of independent and dependent variables were taken from the documents above as a secondary data source. Table 1 shows the research variables, indicators, and sources taken.

Table 1. Variable, Indicator, and Source of Data

\begin{tabular}{|l|l|c|}
\hline \multicolumn{1}{|c|}{ Variables } & \multicolumn{1}{|c|}{ Indicators } & $\begin{array}{c}\text { Source of } \\
\text { Data }\end{array}$ \\
\hline ICT asset management & Government online presence & {$[23]$} \\
\hline General asset management & General infrastructure & {$[23]$} \\
\hline
\end{tabular}




\begin{tabular}{|l|l|c|}
\hline \multicolumn{1}{|c|}{ Variables } & \multicolumn{1}{|c|}{ Indicators } & $\begin{array}{c}\text { Source of } \\
\text { Data }\end{array}$ \\
\hline Government effectiveness & Government effectiveness & {$[23]$} \\
\hline Community education & Education & {$[23]$} \\
\hline Utilization of ICT by the community & ICT use & {$[23]$} \\
\hline Living environment & Ecological sustainability & {$[23]$} \\
\hline Freedom of opinion & Voice & {$[24]$} \\
\hline Islam & Percent of followers of Islam & {$[25]$} \\
\hline Community involvement in e-government & e-Participation & {$[23]$} \\
\hline
\end{tabular}

There are some notes of the indicators above. The government online presence indicator is an index that measures the quality of government websites in a country including national portals, online service portals, and websites of ministries and government agencies. General infrastructure includes logistics, electricity, and capital infrastructure. The effectiveness of government includes the quality of public services, government freedom from pressure from political parties, the quality of policy formulation and implementation, and the government's commitment credibility to the policies that have been made. Environmental variables include energy use, environmental performance, and ISO 14001 certificates. Freedom of opinion includes aspects of freedom to elect regional head or representative, freedom of opinion, freedom of association, and freedom of the press. These variables in their original form is a range from -2.5 to 2.5 . We convert it into an index form with the formula $(x+2.5) * 20$ so that the resulting value is always in the range 1-100 as in the other indexes. The percentage of adherents of Islam partially has range data. In this case, we use the middle value of the range. Some other data are estimated values of $<0.01 \%$. We use a value of 0.01 if we find this kind of data. Table 2 shows the descriptive statistics of the research variables, while Figure 1 shows the research model.

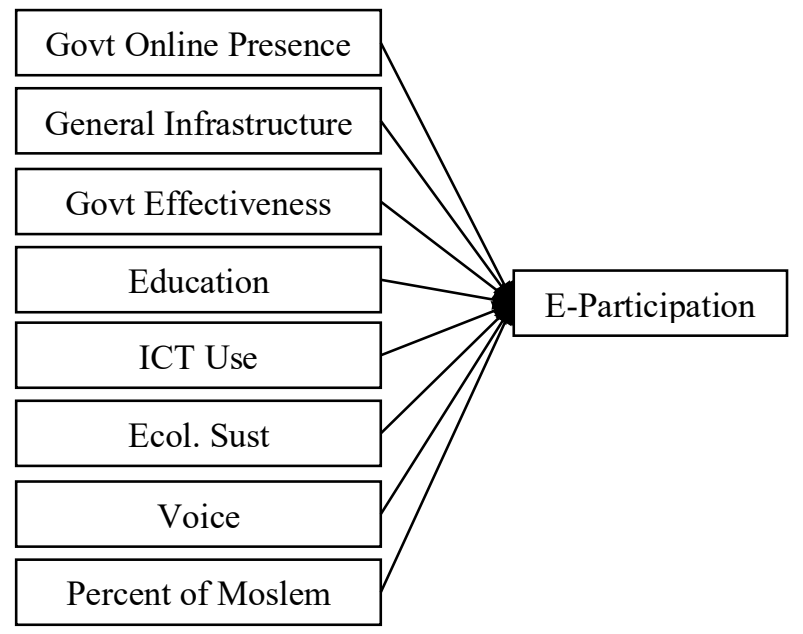

Fig. 1. The Research Model 
Table 2. Descriptive Statistics of Research Variables

\begin{tabular}{|c|c|c|c|c|c|}
\hline Variables & $\mathbf{N}$ & Min & Max & Mean & SD \\
\hline $\begin{array}{l}\text { Government online } \\
\text { presence }\end{array}$ & 128 & 9.70 (Yemen) & 100 (Denmark) & 69.19 & 21.56 \\
\hline General infrastructure & 129 & 0.20 (Burundi) & 68.50 (Norway) & 35.43 & 12.68 \\
\hline Government effectiveness & 128 & 14.10 (Burundi) & 100 (Singapore) & 52.63 & 21.38 \\
\hline Education & 128 & 13.80 (Guinea) & $\begin{array}{c}92.20 \text { (Bosnia } \\
\text { and } \\
\text { Herzegovina) }\end{array}$ & 46.42 & 14.72 \\
\hline ICT use & 126 & 6.10 (Burundi) & 90.00 (Denmark) & 52.04 & 23.60 \\
\hline Ecological sustainability & 129 & 17.6 (Nepal) & 72.80 (Malta) & 39.52 & 12.32 \\
\hline Voice & 126 & 14.99 (Yemen) & 84.85 (Norway) & 52.44 & 18.29 \\
\hline $\begin{array}{l}\text { Percent of followers of } \\
\text { Islam }\end{array}$ & 129 & $\begin{array}{c}0.01 \text { (Mexico \& } \\
\text { Moldova) }\end{array}$ & 99.80 (Turkey) & 25.61 & 35.44 \\
\hline E-Participation & 128 & 11.80 (Yemen) & $\begin{array}{c}100 \text { (Republic of } \\
\text { Korea, Denmark, } \\
\text { and Finland) }\end{array}$ & 69.59 & 22.79 \\
\hline
\end{tabular}

The hypothesis is tested using multiple linear regression analysis. Multiple linear regressions are implemented in 121 countries with complete data out of the 129 countries in the database. All variables were included because the multicollinearity test did not find a very high correlation between the independent variables (VIF $<10) . \mathrm{R}^{2}$ statistics and adjusted $\mathrm{R}^{2}$ show high explanatory capacity models $(0.947$ and 0.944$)$.

\section{Results and Discussion}

Table 3 display show government online presence positively associates with eparticipation, while government effectiveness negatively associates with e-participation. Table 3 further shows that public infrastructure, ecological sustainability and voice positively relate to the e-participation education, the use of ICT, and Islam have no significant effect on eparticipation.

Table 3. Regression Predicts e-Participation

\begin{tabular}{|l|c|c|}
\hline \multicolumn{1}{|c|}{ Predictors } & B & SE \\
\hline Government online presence & $-0.988^{* * *}$ & 0.035 \\
\hline General infrastructure & $0.049^{*}$ & 0.051 \\
\hline Government effectiveness & $-0.202^{* * *}$ & 0.056 \\
\hline Education & 0.031 & 0.046 \\
\hline ICT use & 0.017 & 0.048 \\
\hline Ecological sustainability & $0.073^{* *}$ & 0.062 \\
\hline Voice & $0.067^{*}$ & 0.045 \\
\hline Percent of followers of Islam & -0.021 & 0.017 \\
\hline \multicolumn{2}{|c|}{$* p<0.10 ;{ }^{* *} p<0.05 ; * * p<0.01$} \\
\hline
\end{tabular}


Table 4 shows a comparison of the results of our study with those of the previous researches on the antecedents of e-participation.

Table 4. Comparison of Related Research

\begin{tabular}{|c|c|c|c|c|}
\hline Research & Lee and Kim [7] & Azam [8] & Zolotov et al. [9] & This study \\
\hline Design & Cross-sectional & Cross-section & Meta-analysis & Cross-sectional \\
\hline Data & $\begin{array}{l}813 \text { Korean e- } \\
\text { participation } \\
\text { survey } \\
\text { respondents }\end{array}$ & 192 countries & $\begin{array}{ll}60 & \text { research } \\
\text { results } & \end{array}$ & 129 countries \\
\hline $\begin{array}{l}\text { Analysis } \\
\text { technique }\end{array}$ & $\begin{array}{l}\text { Logistic } \\
\text { regression }\end{array}$ & $\begin{array}{l}\text { Ordinary least } \\
\text { square }\end{array}$ & Meta-analysis & $\begin{array}{l}\text { Multiple } \\
\text { Regression }\end{array}$ \\
\hline $\begin{array}{l}\text { Dependent } \\
\text { Variable }\end{array}$ & $\begin{array}{l}\text { Participation level } \\
\text { e-participation }\end{array}$ & E-participation & $\begin{array}{l}\text { Intention to use e- } \\
\text { participation }\end{array}$ & E-participation \\
\hline Predictor & $\begin{array}{l}\text { Trust in } \\
\text { government ( } \mathrm{p} \\
<0.05 \text { ); strength } \\
\text { of social ties ( } \mathrm{p} \\
<0.05 \text { ); } \\
\text { responsiveness ( } \mathrm{p} \\
<0.10 \text { ); intention } \\
\text { to use ( } \mathrm{p}<0.01) \text {; } \\
\text { age }(\mathrm{p}<0.01) \text {, } \\
\text { education (p } \\
<0.05) \text {; income ( } \mathrm{p} \\
<0.01) \text {; duration } \\
\text { of government } \\
\text { discussion forum } \\
\text { membership ( } \mathrm{p} \\
<0.01) \text {; frequency } \\
\text { of forum visits ( } \mathrm{p} \\
<0.01) \text {; election } \\
\text { participation ( } \mathrm{p} \\
<0.05 \text { ) }\end{array}$ & $\begin{array}{l}\text { IQ }(\mathrm{p}<0.01) ; \\
\text { internet user } \\
(\mathrm{p}<0.01) ; \\
\text { political } \\
\text { globalization } \\
(\mathrm{p}<0.01) ; \\
\text { press freedom } \\
\text { ( }<<0.01) ; \\
\text { British legal } \\
\text { origin (p } \\
<0.01) ; \text { French } \\
\text { legal origin ( } \mathrm{p} \\
<0.01) ; \\
\text { Muslim } \\
(\text { negative; } \mathrm{p} \\
<0.01) ; \mathrm{UV} \\
\text { exposure } \\
(\text { negative; } \mathrm{p} \\
<0.1) ; \text { Europe } \\
(\mathrm{p}<0.01) ; \\
\text { Asia (p } \\
<0.01) ; \\
\text { America (p } \\
<0.01) ; \text { Pacific } \\
(\mathrm{p}<0.01) ; \\
\text { government } \\
\text { effectiveness } \\
(\mathrm{p}<0.01) ; \\
\text { urbanization } \\
(\mathrm{p}<0.01) ; \text { area } \\
(\mathrm{p}<0.001)\end{array}$ & $\begin{array}{l}\text { Image, relative } \\
\text { advantage, } \\
\text { attitude, perceived } \\
\text { usefulness, } \\
\text { perceived } \\
\text { convenience, } \\
\text { social influence, } \\
\text { business } \\
\text { expectations, } \\
\text { subjective norms, } \\
\text { trust, trust in } \\
\text { government, trust } \\
\text { in internet (all p } \\
<0.05 \text { ) }\end{array}$ & $\begin{array}{l}\text { Government } \\
\text { online presence } \\
\text { ( } p<0.001) ; \\
\text { public } \\
\text { infrastructure ( } p \\
<0.1) \text {; } \\
\text { government } \\
\text { effectiveness } \\
\text { (negative, } p \\
<0.001 \text { ); } \\
\text { education (not } \\
\text { significant); use } \\
\text { of ICT (not } \\
\text { significant); } \\
\text { ecological } \\
\text { sustainability ( } p \\
<0.05 \text { ); freedom } \\
\text { of opinion ( } p \\
<0.1 \text { ); Islam } \\
\text { (insignificant) }\end{array}$ \\
\hline
\end{tabular}


From the table above, we can ignore the results of the study by Zolotov et al. [9] and Lee and Kim [7] because their studies are at individual level. Only Azam's [8] study is at country level, so, it can be compared with current researches. However, it differs in a number of results compared to the current researches. Azam [8] found that IQ has a significant effect on e-participation. IQ strongly correlates with education, but current research now does not find a significant effect of education on e-participation, in line with Liden's research results [6] but contrary to the findings of [26]. It makes sense that the more intelligent and educated the citizens are, the more they want to participate, but even less educated people can be taught to use the internet and participate in e-government.

Our findings are consistent with Azam [8] in terms of the significant influence of freedom of speech (freedom of the press). We do not include variables of the legal origin of a country because this is too premature. Although colonially a country can inherit its colonial legal system, this does not mean that there are no mixing or new legal innovations that deviate from the colonial origins, especially in aspects related to information technology. We also do not include the continent of origin because this is something imaginary, at least for countries outside Europe. Apart from the European Union, there is no cultural or legal unity binding on other continents in the world. We leave out UV exposure because this physical effect is thought to be related to intelligence which was proven to have no significant effect. We do not include urbanization because the measurement of urbanization is biased and the definition of city and village is not clear in modern society. Moreover, aspects of the urban-rural gap have been facilitated by the government's online presence variable. We do not include the total area because we consider this variable to be too simplistic. Many countries are large because of their desert region. The area does not take into account the slope of the land which allows more people to live in a narrow space.

We, however, also use Islamic variables. Azam [8] did not provide an argument why Muslim majority countries have lower participation than non-Muslim countries. It only states that Islam influences e-participation. This assumption seems to be rooted in the literature on Muslim participation in the United States [27][29]. It is clear that many Muslim-majority countries today are very democratic and they encourage public participation [30]. We included the same Islamic variables used by Azam [8] but did not find a significant effect.

What is new and interesting is that the effectiveness of government has a negative effect on e-participation. This means that the more effective the government is, the less citizens participation is. Even so, this can be understood because the community views that ineffective government must be corrected immediately by community participation. This means that people use ICT to correct government. This is especially because there is a significant relationship between government ICT assets and e-participation. We conducted robustness tests with a variety of variables from the Global Innovation Index Duta et al. [23] and this relationship remained valid and significant.

Other significant variables are ecological sustainability and public infrastructure. These variables positively affect e-participation. This might relate to trust as what was found by Lee and Kim [7] and Zolotov et al. [9] with a sustainable ecology and good infrastructure, the community's trust in the government increases and, due to this, the community participates. An alternative explanation is that ecological sustainability is seen as a result of community correction to the government and therefore, the community continues to correct the government to get more positive results. This explains why at the same time the government effectiveness has a negative effect. The finding suggests that the community views that government performance in the environment and infrastructure does not mean good performance in other fields, and perhaps, the community views that the ecological 
sustainability and quality of infrastructure are the results of their labor in correcting the government, and therefore, will continue doing so.

There is no significant effect of the education variable, in line with Liden's research [6]. The use of ICT by the community shows no significant effect as well, indicating that the community has become accustomed to ICT so that even at a low level, ICT can be used for participation.

In general, this research shows that the utilization of information technology assets of public institutions in the form of online government presence encourages public participation. The purpose of this participation is to correct and assist the government in carrying out its duties, especially if the public considers the government to have low effectiveness.

Future research can further explore the elements of government online presence, ecological sustainability, government ineffectiveness, and freedom of speech that influence eparticipation. Other variables can also be explored such as the level of cyber security and public-private partnerships as surveyed by [31]. We initially wanted to include this variable but the available data is only in the form of ranking (and is therefore not normal) and is also limited to a few countries. It is possible that safety factors can also play a role as indicated in the literature of individual studies [9]. Public-private partnerships also relate to government assets and can be used if more complete and accurate data are available [32]. Likewise, the government service quality variable from In CISE [33] can be extended to more countries to be used as a variable in predicting e-participation.

Future studies also need to examine other variables such as GDP. Previous research found an insignificant relationship between GDP and e-participation Azam and Joseph et al. [8][10] so we did not include this variable in the research model. But it is possible that GDP has a non-linear effect on e-government and e-participation [34]. Other variables can include influencing external variables such as FDI and import of ICT commodities and foreign financial assistance because there is a possibility that external factors can also influence a country's information technology asset policy as formulated by the exogenous growth theory $[15][37][38]$.

The findings of this study encourage optimism lacked in the previous research that viewed the government as unable to boost e-participation [39][40]. (Current research shows that the intensity of government investment in ICT has led to administrative reform through citizen involvement. Therefore, this research has practical implications on government efforts to improve the quality of e-government in various countries to encourage public participation in improving government effectiveness.

This study, however, has limitations. This study uses cross-sectional data in 2019 instead of the data from many years at once. The advantage of this data is that the results obtained are consistent for the present and are not affected by changes that have been made in the past. Even so, this is also a weakness of this study because it means that in the future, this relationship might change and some variables become insignificant while new variables appear or old variables that were not significant become significant. This is a common limitation in research involving rapidly evolving technological variables [38].

\section{Conclusion}

A government online presence has a big positive impact on e-participation. As this research shows, this applies to all countries in the world, both developed and developing countries and even the least developed. Furthermore, the effectiveness of governance has a big 
negative impact on e-participation, signaling that in various contexts, people perceive the open space by ICT as enabling them to criticize, provide input, and assist the government in becoming more effective at work.

From an asset management perspective, investment and ICT asset management carried out by governments in the world today are not as bleak as those previously thought. Countries that have sacrificed large budgets to build servers and maintain them and respond well to citizens get satisfactory investment returns with enthusiastic citizen participation. Despite getting uncomfortable criticism, the government needs the input to guide them in providing the best service for the community. The government's response, in this case, is to continue to show good work results, in the form of asset management and infrastructure that are increasingly satisfying, so that people know that their input is heard, considered, and implemented for their interests, as it should be in a democratic country.

\section{References}

[1] E. Dobrolyubova, E. Klochkova, and O. Alexandrov, "Digitalization and Effective Government: What Is the Cause and What Is the Effect?," in International Conference on Digital Transformation and Global Society, 2019, pp. 55-67.

[2] I. Gvenetadze, "Georgia's Successful Journey to E-Government," 2016.

[3] J. Millard, "European strategies for e-governance to 2020 and beyond," in Government 3.0 Next Generation Government Technology Infrastructure and Services, Cham, Switzerland: Springer, 2017, pp. 1-25.

[4] S. C. Lim, "From Internet of Things to Open and Big Data," IAC Online J., vol. 1, no. 01, pp. 57-58, 2017.

[5] N. Ž. Hrustek, A. Prosser, and V. Dušak, "A Multidimensional Model of E-Inclusion and its Implications," in CEE eDem and EGov Days, 2016, pp. 435-447.

[6] G. Liden, "Progress in Global Assessments of E-Democracy: Refined Measurements and New Findings," in International E-Government Development: Policy, Implementation and Best Practice, L. Munoz and M. Bolivar, Eds. Cham, Switzerland: Palgrave Macmillan, 2018, pp. 215-238.

[7] J. Lee and S. Kim, "Citizens ' e-participation on agenda setting in local governance: Do individual social capital and e- participation management matter?," Public Manag. Rev., vol. 20, no. 6, pp. 873-895, 2018, doi: 10.1080/14719037.2017.1340507.

[8] S. Azam, "Does intelligence explain why nations differ in online political participation?," 2016.

[9] M. N. Zolotov, T. Oliveira, and S. Casteleyn, "E-participation adoption models research in the last 17 years : A weight and meta-analytical review," Comput. Human Behav., vol. 81, pp. 350365, 2018, doi: 10.1016/j.chb.2017.12.031.

[10] A. Das, H. Singh, and D. Joseph, "A Longitudinal Study of e-Government Maturity," Inf. Manag., vol. 54, no. 4, pp. 415-426, 2017, doi: 10.1016/j.im.2016.09.006.

[11] J. N. Baldwin, R. Gauld, and S. Goldfinch, "What Public Servants Really Think of EGovernment," Public Manag. Rev., vol. 14, no. 1, pp. 105-127, 2012, doi: 10.1080/14719037.2011.589616.

[12] K. L. Kraemer and J. King, "Information technology and administrative reform: will egovernment be different?," Int. J. Electron. Gov. Res., vol. 2, no. 1, pp. 1-20, 2005.

[13] G. Lappas, P. Yannas, A. Triantafillidou, A. Kleftodimos, and O. Vasileiadou, "Modeling a Citizen-Centric Evaluation Framework for Local e-Government and e-Democracy," Int. J. Educ. Inf. Technol., vol. 10, pp. 120-130, 2016.

[14] K. Diga, "Voice or Chatter? State of the Art - Country Overview: South Africa," 2017.

[15] S. Lakka, T. Stamati, C. Michalakelis, and D. Martakos, "What drives eGovernment growth? An econometric analysis on the impacting factors," Int. J. Electron. Gov., vol. 6, no. 1, pp. 20 36, 2013.

[16] W. R. Scott, "Institutional Theory : Contributing to a Theoretical Research Program," in Great 
Minds in Management: The Process of Theory Development, K. Smith and M. A. Hitt, Eds. Oxford: Oxford University Press, 2004.

[17] D. North, Institutions, Institutional Change and Economic Performance. Cambridge: Cambridge University Press, 1990.

[18] P. M. Romer, “The Origins of Endogenous Growth,” J. Econ. Perspect., vol. 8, no. 1, pp. 3-22, 1994.

[19] S. Cesaratto, "Endogenous Growth Theory Twenty Years on : A Critical Assessment," Bull. Polit. Econ., vol. 4, no. 1, pp. 1-30, 2010.

[20] W. Jho and K. Song, "Institutional and technological determinants of civil e-Participation : Solo or duet ?," Gov. Inf. Q., vol. 32, pp. 488-495, 2015, doi: 10.1016/j.giq.2015.09.003.

[21] T. Nam, "Does E-Government Raise Effectiveness and Efficiency? Examining the Crossnational Effect," J. Glob. Inf. Manag., vol. 27, no. 3, pp. 120-138, 2019.

[22] M. I. Merhi and K. S. Koong, "E-government effectiveness : a rocket model of contributing user-related factors," Int. J. Serv. Oper. Manag., vol. 11, no. 1, pp. 1-19, 2016.

[23] S. Dutta, B. Lanvin, and S. Wunsch-Vincent, Global Innovation Index 2019: Creating Healthy Lives - The Future of Medical Innovation. World Intellectual Property Organization, 2019.

[24] The World Bank, “The Worldwide Governance Indicators , 2019 Update,” 2019.

[25] Pew Research Center, "Religious Composition by Country," 2012.

[26] R. Pérez-Morote, C. Pontones-Rosa, and M. Nunez-Chicharo, "The effects of e-government evaluation, trust and the digital divide in the levels of e-government use in European countries," Technol. Forecast. Soc. Chang., vol. 154, 2020, doi: 10.1016/j.techfore.2020.119973.

[27] J. W. Ayers and C. R. Hofstetter, “American Muslim Political Participation Following 9 / 11 : Religious Belief, Political Resources, Social Structures, and Political Awareness," Polit. Relig., vol. 1, pp. 3-26, 2008, doi: 10.1017/S1755048308000023.

[28] P. Djupe and J. T. Grant, "Religious Institutions and Political Participation in America," J. Sci. Study Relig., vol. 40, no. 2, pp. 303-314, 2001.

[29] H. E. Brady, S. Verba, and K. L. Schlozman, "Beyond SES: A Resource Model of Political Participation," Am. Polit. Sci. Rev., vol. 89, no. 2, pp. 271-294, 1995.

[30] S. Ciftci, F. M. Wuthrich, and A. Shamaileh, "Islam, Religious Outlooks , and Support for Democracy," Polit. Res. Q., vol. 72, no. 2, pp. 435-449, 2019, doi: $10.1177 / 1065912918793233$.

[31] IMD, "IMD World Digital Competitiveness Ranking 2018," 2018.

[32] S. Kim and C. Choi, "Institutional and Managerial Dimensions of Digital Government Development in the Republic of Korea," in Bringing Government into the 21st Century: The Korean Digital Governance Experience, T. Karippacheril, S. Kim, R. Beschel Jr, and C. Choi, Eds. The World Bank, 2016, pp. 13-40.

[33] InCiSE, “The International Civil Service Effectiveness (InCiSE) Index 2019,” 2019.

[34] F. Cruz-Jesus, T. Oliveira, F. Bacao, and Z. Irani, "Assessing the pattern between economic and digital development of countries," Inf. Syst. Front., vol. 19, no. 4, pp. 835-854, 2017, doi: 10.1007/s10796-016-9634-1.

[35] N. Kaldor, "Capital accumulation and economic growth," in The Theory of Capital: Proceedings of a Conference held by the International Economic Association, 1961, pp. 177222.

[36] R. M. Solow, "A Contribution to the Theory of Economic Growth," Q. J. Econ., vol. 70, no. 1, pp. 65-94, 1956.

[37] D. F. Norris, "E-Government ... Not E-Governance ... Not E-Democracy Not Now! Not Ever?," in Proceedings of the 4th International Conference on Theory and Practice of Electronic Governance, 2010, pp. 339-346.

[38] D. F. Norris, "E-Government 2020: Plus ça change, plus c'est la meme chose," Public Adm. Rev., vol. 70, no. S1, pp. S180-181, 2010. 